Mara Coelho de Souza Lago'

'Universidade Federal de Santa Catarina, Florianópolis, SC, Brasil

\title{
Vicissitudes of Internationalization: Academic articles in Brazilian journals
}

\begin{abstract}
In 2017, Revista Estudos Feministas completed 25 years of publication. Its 10, 15 and 20 years as an academic journal created and edited by women's groups linked to teaching, research and feminist activism have yielded many texts in commemorative editions. REF, the result of a voluntary collective work, "is an indexed, interdisciplinary journal of national and international circulation, the mission of which is to publish articles, essays and reviews that present consistent and innovative theoretical reflections (...) broadening the frontiers of academic debates in the field of feminist and gender studies and implementing the practices of women's movements". The $25^{\text {th }}$ anniversary of REF provides us with a new opportunity to reflect on its editing processes, on the themes of the articles, essays, dossiers and debates produced, as well as on the geographical places and disciplinary formations of their authors, with their diversified epistemological affiliations, now supported by a database that has been organized on the magazine.

Keywords: Revista Estudos Feministas; Authorship; Theme; Diversity
\end{abstract}

This round table gives continuity to one held at Doing Gender 10, in 2013, when those who came together to speak about Feminist Publications included our much-missed companion Zahidé Lupinacci MUZART (2014), who reported on her experience as the publisher of Editora Mulheres; Mara Coelho de Souza LAGO (2014) for the Revista Estudos Feministas, Lucila SCAVONE (2014) with her study about Brazilian feminist and gender-related academic journals; María Luisa FEMENÍAS (2014), for the journal Mora from Argentina; and Claire MOSES (2014), who spoke about Feminist Studies, a pioneer journal in this field.

The organization of these spaces of dialogue and narratives about the activities, interactions and reflections involved in the publishing of feminist writing and writing about gender, has become a tradition among us since the Revista Estudos Feministas - which had proposed an online portal to bring together the publications in this field - organized the I Encontro Brasileiro de Publicações Feministas in 2002 and the I Encontro Internacional and

\section{(c) (7)}

Esta obra está sob licença Creative Commons. 
II Encontro Nacional de Publicações Feministas in 2003, both of which were held in Ponta das Canas, one of the beautiful beaches on Santa Catarina Island.

In 2017 , REF is celebrating 25 years since it was first released in Rio de Janeiro, in 1992. For 19 years it has been edited by us here at UFSC. In fact, its publication was taken on by the collective of feminist researchers at UFSC with considerable fear: it was a great responsibility to maintain the quality of the journal's initial proposal, as conceived by its creators in southeastern Brazil and what they were able to achieve.

Since it came to us, REF has always been linked to the Doing Gender Seminar - it was after Doing Gender 3: Gender and Health, in 1998, that we received the offer to publish it here in Florianópolis. At another of our encounters, the International Seminar Doing Gender 4: Culture, Politics and Sexuality in the $21^{\text {st }}$ Century, we issued a joint transition edition of the journal ( $\left.v .7, n^{\circ} 1 / 2,1999\right)$, behind schedule, yet with a commitment to maintain its frequency. And like the Doing Gender seminar, the Revista Estudos Feministas, which reinforced our group around collective, voluntary and interdisciplinary work, has provided us enriching academic, political and personal experiences, which have been sufficiently highlighted.'

Since the initial proposal of the creators of the journal was that it would not be institutionalized, the publication of REF in Rio de Janeiro moved between the federal and state universities: UFRJ and UERJ. ${ }^{2}$ In Florianópolis, the journal became institutionalized and wound up being edited at UFSC, which provided an exclusive employee, our editorial assistant Carmem Vera Ramos, physical space, equipment and the voluntary work of many professors, from various disciplines, departments and centers of education, especially the Center of Philosophy and Human Sciences (CFH) and the Center of Communication and Expression (CCE), which initially took over the publication.

The rotation of editors, also foreseen in the proposal of the journal and followed in the period in which it was edited in Rio de Janeiro, was observed more faithfully in the early years of the journal here at UFSC. In recent years, with the aging of our staff and the slow renovation of professors dedicated to feminist and gender studies at UFSC ${ }^{3}$ and UDESC who participate in our projects, it has not been easy to accompany the needs for renovation and to incorporate volunteers. Thus, in recent years, the editorial coordination of REF has remained in the hands of a few of us.

But in Florianópolis, due to the voluntary work required for the publication of REF, through a proposal by Luzinete Simões MINELLA (2008) who was then one of the editors, the journal came to have various editors responsible for each one of its different sections in an effort to share the tasks. I gave a detailed description of these sections of REF in a paper presented in the Feminist Publications round table at Doing Gender 11, in 2013 (LAGO, 2014), which was later published in one of the collections produced about the event, Linguagens e narrativas: desafios feministas [Languages and Narrative: Feminist Challenges] organized by Susana B. FUNCK et al. (2014).

1 These reflections are based on information collected from the REF database, organized and updated by Rita Maria Xavier Machado, our partner responsible for the layout of the journal since 1999, to whom we are all indebted. ${ }^{2}$ For a reflection on the first period of REF and the issue of institutionalization, see the article by Albertina Costa (COSTA, Albertina. "Revista Estudos Feministas: primeira fase, locação Rio de Janeiro". Revista Estudos Feministas, Florianópolis, v.12. n.especial, 2004. p. 205-210).

${ }^{3}$ If the hiring of professors in these fields is not satisfactorily fulfilled by the university departments, to provide a sufficient number of researchers needed for our activities, we highlight the education at UFSC of many students at all levels and in various fields of knowledge who are dedicated to feminist and gender studies, and the study of sexualities and diversities, including undergraduate students, those in specialist courses, master's, doctors and post-doctors who are active at various institutions in Santa Catarina and other states and regions of Brazil and other countries. 
On various occasions we have met with the former and current editors of the journal and from other publications to reflect on this editorial adventure. This has usually been on significant dates such as in 2002 (REF's 10 $0^{\text {th }}$ anniversary), 2007 ( $15^{\text {th }}$ anniversary) and in 2012 (marking 20 years of uninterrupted publication). We speak of the tasks, expectations, changes, projects and sharing, and we intensify the production of reflections and reports about the publication of feminist and gender journals, producing many narratives about Revista Estudos Feministas. The researchers who have edited the journal have been called on to produce these reports, with an increasing risk of redundancy (by repeating histories and stories already told and written about, which are mentioned here with an effort by the author to avoid plagiarism, including self-plagiarism).

This time, as we complete 25 years of publication and avoiding complaints - the work, the lack of funds, the difficult deadlines, difficulty finding enough reviewers to meet demand, the delay in returning reviews -, we must mention the difficult decision that we finally made: to stop publishing a print edition.

The last issues of REF on paper were the three issues of volume 23 of 2015 . We no longer publish in this form, with the body of articles organized on the texture of paper, with its weight, smell, color, with the covers which involved so much work (a task shared with Zahidé) and satisfaction in the way that they distinguished the journal. It was a decision delayed yet inexorable - the advances of technology had required it for some time. For me, it was certainly a generational question, it was a difficult decision. But what could we do?

To turn the gaze towards other perspectives: we used to publish 1,000 copies, then 500 , at a high cost. In this virtual form we have an infinitely higher distribution and in the field of the human sciences we are one of the journals with the highest access rates on the SciELO portal (Roberto MENEGHINI, 2013).

It is true that the journal was already online, with free access to all its contents on the SciELO portal, on the Portal de Periódicos da UFSC and on the Portal of IEG (Sônia W. MALUF, 2008). Its publication on paper was thus a bonus that we made an effort to maintain.

Those who index journals, who are highly inspired in their modes of conducting science and evaluating productivity by the so-called hard sciences, have also created impositions and demands to adopt new technologies, and changes quickly followed. We wound up having to submit to these demands, as if the avalanche of recent attacks in Brazil on countless conquests of arduous struggles of feminist and other movements had not been enough. Nevertheless, REF and other journals have accompanied and analyzed the attacks on rights to recognition, respect for differences of race, ethnicity, class, gender, sexualities, of the universal right to citizenship and a decent life with access to education, healthcare, work, housing and equality. This history has been experienced with suffering and reported on in recent years of the journal.

Currently, the strongest of these impositions (both for productivity and publication) is that of the internationalization of our universities, courses and publications. This internationalization initially took place through the adaptation of our different national languages and forms of speech to the hegemonic incorporation of English as a second language. While this has many positive aspects for education at various levels, by creating opportunities for cultural exchanges, a command of new languages and, with them, new knowledge and multicultural experiences, we cannot forget some issues, like the imposition of values, customs, cultures and traditions that belittle our origins and our continents in this globalized world (traditions that are also part of us, constituted as we were as national peoples in imperialist processes of European colonization).

These questions are inherent to and stem from the contemporary times of globalization. 


\section{The Interdisciplinary REF}

In the first extensive study made about REF, covering its first 10 years of publication (1992-2002), the authors Débora DINIZ and Paula FOLTRAN (2004) analyzed the professional fields of the authors (who were still few) published in the journal. Based on this study we conducted a review of the journal from 2003 until today (2017). This overview reiterates and reveals the interdisciplinary character of the production in the field of feminist and gender studies, as well as the fields of the collaborators and editors, within the broad area of the human and social sciences.

Gráfico 1 - Authors by Field of Knowledge. Jan. 2003 - Aug. 2017.

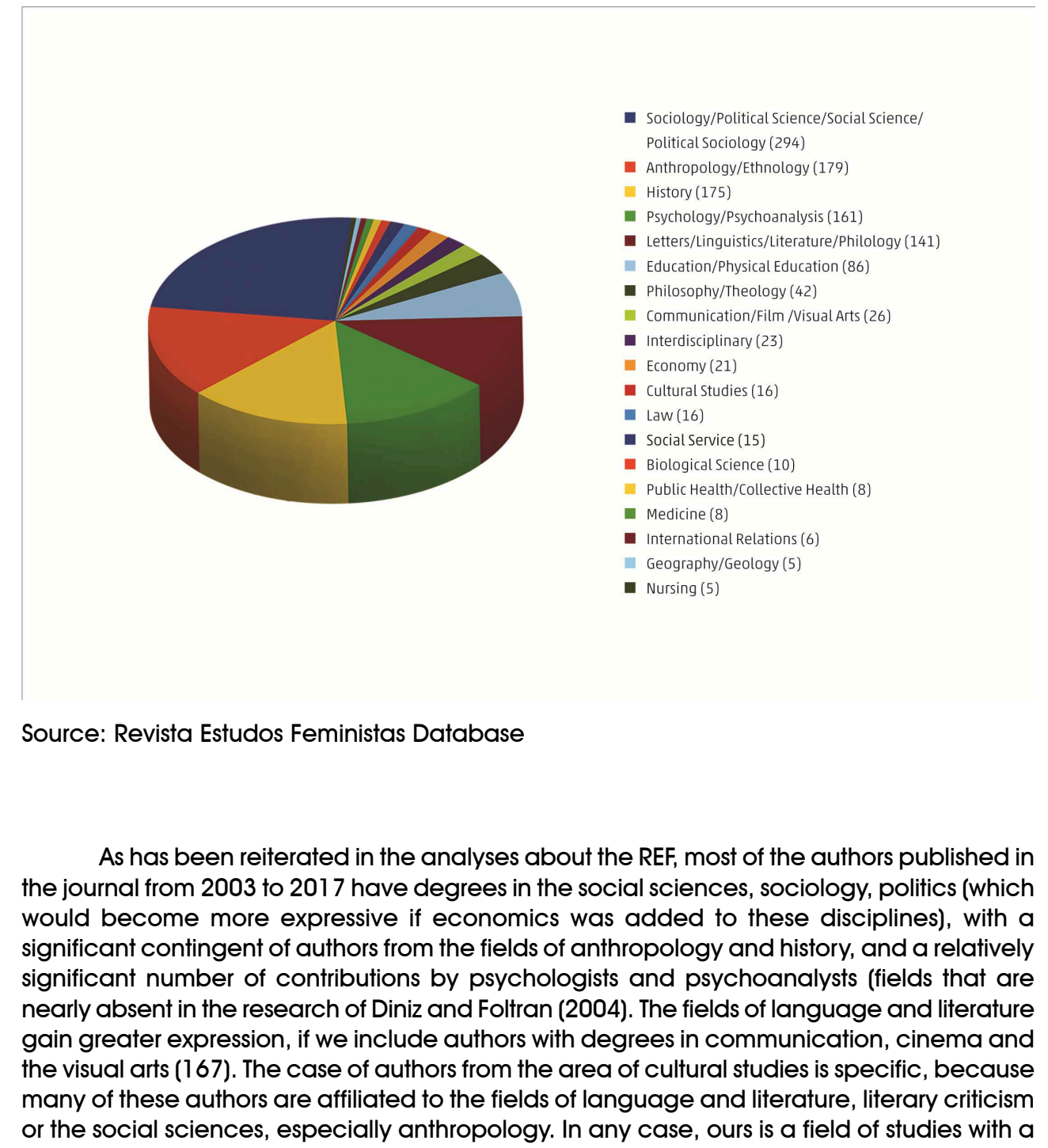

4 Revista Estudos Feministas, Florianópolis, 26(3): e58654 
strong interdisciplinary trait. As we have emphasized at other moments, some fields and disciplines, such as biology, nursing, medicine, public health, still have only an incipient participation in REF. Only recently have we had contributions from authors from the applied social sciences, such as social service and law, or from more recently organized courses such as international relations.

This graph reveals that interdisciplinarity also has a growing presence if we visualize the classification of authors according to the field of their degrees, reiterating that interdisciplinarity is a defining characteristic of feminist studies, and studies of gender and sexualities. Interdisciplinarity is also revealed in the expressive nature that an intersectional perspective has had in the studies and analyses published in the various sections of the journal.

The reflections and productions of the studies about women, feminism and gender in REF, which initially showed a strong influence from Marxist theory and a persistent argument based on concepts of patriarchy (Joan W. SCOTT, 1990), reveal a definite trajectory in the theoretical foundations of these texts, from a Marxist paradigm and from socio-anthropological studies of patriarchy, to structuralist, post-structuralist and deconstructionist theories, to queer and decolonial studies. This trajectory is not linear because, as Roberto CARDOSO DE OLIVEIRA (1985) highlighted, in the social sciences new paradigms based on new scientific discoveries do not eliminate older theories, as Kuhn affirms for the hard sciences, but paradigms in the social sciences continue to exist convivially within the disciplines and among different disciplinary matrixes.

Parallel to the epistemological developments that have enriched the academic journals in the field of gender studies, we have experienced in Brazil deep struggles with social forces that strive to eliminate the category of gender and its study from educational curricula, defending a "non-partisan school" in the practice of education without feminism, without the study of differences, inequalities, without criticism of prejudices, racisms, sexisms, of homophobia, lesbophobia and transphobia. On a theoretical plane, there have been many advances, paths, reflections and research; on the professional and practical plane there has been a regression, and energy must be invested to maintain the always partial conquests of social movements.

\section{The paths of Internationalization}

As we look at the process of internationalization of our journals, it becomes clear that publications in other languages than English take a secondary place. Such is the case of Spanish, a language we have particularly invested in to become closer to our neighbors from Mercosur in particular. In the study mentioned about the articles published in the first 10 years of REF, Débora Diniz and Paula Foltran (2004) emphasize in their conclusion that while there was a "strengthening of the international dialog, in particular with U.S. and French authors, there was only a sparse exchange with Latin America" (p. 251). But in the recent past of the journal, and in part due to the expansion of Doing Gender, we have seen a significant increase in our interaction with Latin America, especially with the Mercosur countries, which do not speak our language. Today, about $20 \%$ of REF's content is published in Spanish.

In contrast to the trend towards internationalization dictated by the main indexers of Brazilian publications and by the institutions that define educational policies in the country, there has been an increasing presence in REF of the themes of decolonization and decolonial feminisms. This is a valorization of the cultural production of the colonized, in a shift of the movements of theories, arts, traditions - which traditionally took place from North to South and which now emphasize new directions, from South to South. As a focus of the debates, 
dossiers, articles and reviews, this theme has shifted perspectives to valorize languages and productions from the Southern portion of the American continent and other continents that also experienced the processes of colonization.

The analyses based on post- and decolonial concepts gained space in the journal in discussions of the translations and travels of these theories (Claudia de Lima COSTA, 2000; SÔNIA E. ALVAREZ, 2009) in new directions. Before being reinforced in the debate sections (table 1), which began with reflections about the classic text of Gloria ANZALDÚA (2000), Mestiza (2000), the theme was already present in interviews (Mary Louise PRATT, 1999; Ella SHOHAT, 2001), in articles such as the translation of the beautiful text by Shohat (2002), in discourses and analyses that were establishing themselves in new debates, such as those found in the texts of Deepika BAHRI (2013) and Maria LUGONES (2014), and in new interviews, like those with Shohat and Stam (in Emanuelle SANTOS; Patricia SCHOR, 2013), and with authors from countries beyond the so-called center - from North America and Europe.

Table 1 - Debate Section

\begin{tabular}{|l|l|l|l|l|}
\hline Vol. & Issue/Year & Author in debate & Themes & Organizers \\
\hline 13 & $3 / 2005$ & Gloria Anzaldua & Mestizaje & $\begin{array}{l}\text { Claudia de L. Costa } \\
\text { Eliana Ávila }\end{array}$ \\
\hline 14 & $3 / 2006$ & $\begin{array}{l}\text { Mary } \\
\text { Hawkesworth }\end{array}$ & Post-feminism Translations & $\begin{array}{l}\text { Eliana Ávila } \\
\text { Claudia de L. Costa }\end{array}$ \\
\hline 17 & $1 / 2009$ & Clare Hemmings & $\begin{array}{l}\text { Intertwined Histories/Stories of } \\
\text { Feminism(s) }\end{array}$ & Claudia de L. Costa \\
\hline 21 & $2 / 2013$ & Deepika Bahri & $\begin{array}{l}\text { Feminism and/in } \\
\text { Postcolonialism }\end{array}$ & Claudia de L. Costa \\
\hline 22 & $3 / 2014$ & Maria Lugones & $\begin{array}{l}\text { Coloniality of Gender and } \\
\text { Decolonial Feminisms }\end{array}$ & Claudia de L. Costa \\
\hline 25 & $2 / 2017$ & Stacy Alaimo & $\begin{array}{l}\text { The Anthropocene, The } \\
\text { Post-Human, and The New } \\
\text { Materialism }\end{array}$ & $\begin{array}{l}\text { Claudia de L. Costa } \\
\text { Susana Borné Funck }\end{array}$ \\
\hline
\end{tabular}

Source: Revista Estudos Feministas.

But it is also true that in terms of the interviews published by REF, we have a significant gap in relation to authors from Latin American countries and other continents arbitrarily known as the global South.

\section{To conclude, a brief look at other sections of REF}

An analysis of the Table of Interviews published in REF (table 2) reveals the countries of the people interviewed, as well as their professional education. It also shows the gradual inclusion of male researchers interviewed.

Not considering the interview of Leila Diniz with the PASQUIM, which was republished in REF, v. 2, n. 2 of 1994, in a dossier dedicated to the actress, we have published 45 interviews with people related to feminist and gender studies. Almost all of the interviews were conducted by or for the journal.

Beginning with the interview with Joan Scott published in 1998, until issue n.3 of volume 25 of 2017,35 cis women, six cis men and three people who self-identify as trans have been interviewed. Conducting the interviews, we calculated 45 women, most of them 
Table 2 - Interview Table

\begin{tabular}{|c|c|c|c|c|c|}
\hline Vol. & $\begin{array}{l}\text { Issue } \\
\text { Year }\end{array}$ & Interviewee & Interviewer & Area & Country \\
\hline 6 & $1 / 1998$ & Joan Wallach Scott & $\begin{array}{l}\text { Mirian Grossi } \\
\text { Maria Luiza Heilbom } \\
\text { Carmen Rial }\end{array}$ & History & France \\
\hline 6 & $2 / 1998$ & Sheila Rowbotham & \begin{tabular}{|l} 
Bila Sorj \\
Mirian Goldenberg
\end{tabular} & History & $\begin{array}{l}\text { United } \\
\text { Kingdom }\end{array}$ \\
\hline 7 & 1-2/1999 & Mary Louise Pratt & $\begin{array}{l}\text { Claudia de Lima Costa } \\
\text { Alai Garcia Diniz }\end{array}$ & Literature & EUA \\
\hline 8 & $1 / 2000$ & Hilary Wainright & \begin{tabular}{|l} 
Bila Sorj \\
Mirian Goldenberg
\end{tabular} & Philosophy & $\begin{array}{l}\text { United } \\
\text { Kingdom }\end{array}$ \\
\hline 8 & $2 / 2000$ & James N, Green & José Gatti & History & USA \\
\hline 9 & $1 / 2001$ & Ella Shohat & $\begin{array}{l}\text { Sônia Weidner Maluf } \\
\text { Claudia de Lima Costa }\end{array}$ & $\begin{array}{l}\text { Cinema and } \\
\text { Postcolonial Studies }\end{array}$ & USA \\
\hline 10 & $1 / 2002$ & Judith Butler & $\begin{array}{l}\text { Baukje Prins } \\
\text { Irene Costera Meijer }\end{array}$ & Philosophy & USA \\
\hline 10 & $2 / 2002$ & Robbie Davis-Floyd & Carmen Susana Tornquist & Anthropology & USA \\
\hline 11 & $1 / 2003$ & Françoise Thébaud & Janine Gomes da Silva & History & France \\
\hline 11 & $2 / 2003$ & Michelle Perrot & Ingrid Galster & History & France \\
\hline 12 & $1 / 2004$ & Marysa Navarro & $\begin{array}{l}\text { Claudia de Lima Costa } \\
\text { Simone Pereira Schmidt }\end{array}$ & History & Spain \\
\hline 12 & $2 / 2004$ & Gabrielle Houbre & Marlon Salomon & History & France \\
\hline 13 & $1 / 2005$ & Luc Capdevila & Joana Maria Pedro & History & France \\
\hline 13 & $2 / 2005$ & Laura Mulvey & REF & $\begin{array}{l}\text { Cinema and } \\
\text { Psychoanalysis }\end{array}$ & $\begin{array}{l}\text { United } \\
\text { Kingdom }\end{array}$ \\
\hline 13 & $3 / 2005$ & Michèle Ferrand & \begin{tabular}{|l|} 
Carmen Rial \\
Mara Coelho de Souza \\
Lago \\
Miriam Pillar Grossi
\end{tabular} & Sociology & France \\
\hline 14 & $1 / 2006$ & Ivone Gebara & Maria José Rosado Nunes & \begin{tabular}{|l} 
Philosophy and \\
Religious Sciences
\end{tabular} & Brazil \\
\hline 14 & $3 / 2006$ & Shirley Malcom & $\begin{array}{l}\text { Carmen Silvia Rial } \\
\text { Miriam Pillar Grossi } \\
\text { Betina Stefanello Lima }\end{array}$ & $\begin{array}{l}\text { Education and Human } \\
\text { Resources }\end{array}$ & USA \\
\hline 15 & $1 / 2007$ & Toril Moi & $\begin{array}{l}\text { Susana Bornéo Funck } \\
\text { Rita Terezinha Schmidt }\end{array}$ & Literature & Norway \\
\hline 15 & $2 / 2007$ & Dona Adèlia Schmitz & \begin{tabular}{|l} 
Maria Ignez Paulilo \\
Cristiani Bereta da Silva
\end{tabular} & \begin{tabular}{|l|} 
Leader of Women \\
Farmers' Movement-SC
\end{tabular} & Brazil \\
\hline 15 & $3 / 2007$ & Chiara Vangelista & $\begin{array}{l}\text { Cristina Scheibe Wolff } \\
\text { Joana Maria Pedro }\end{array}$ & History & Italy \\
\hline 16 & $1 / 2008$ & Heloneida Studart & Roselane Neckel & State Representative & Brazil \\
\hline 16 & $1 / 2008$ & Azadeh Kian-Thiębaut & Carmen Rial & Sociology & Iran \\
\hline 16 & $2 / 2008$ & Martin Dufresne & Carmen Susana Tornquist & Joumalism & Canada \\
\hline
\end{tabular}




\begin{tabular}{|c|c|c|c|c|c|}
\hline 17 & $1 / 2009$ & Eulalia Pérez Sedeño & $\begin{array}{l}\text { Cristina T. da C. Rocha } \\
\text { Miriam Pillar Grossi }\end{array}$ & Philosophy & Moroceo \\
\hline 17 & $1 / 2009$ & Maria Luisa Femenias & Carmen Rial & Philosophy & Argentina \\
\hline 18 & $1 / 2010$ & Judith Butler & Patricia Porchat Knudsen & Philosophy & USA \\
\hline 18 & $2 / 2010$ & Saskia Sassen & Carmen Rial & Sociology & Netherlands \\
\hline 19 & $1 / 2011$ & Heleieth Saffioti & $\begin{array}{l}\text { Juliana C. Mendes } \\
\text { Simone Becker }\end{array}$ & Philosophy & Brazil \\
\hline 19 & $2 / 2011$ & Rebecca Cook & Débora Diniz (trans.) & Law & Canada \\
\hline 20 & $1 / 2012$ & Nalu Faria & $\begin{array}{l}\text { Carmen Susana Tomquist } \\
\text { Soraya Resende Fleischer }\end{array}$ & Psychology & Brazil \\
\hline 20 & $2 / 2012$ & $\begin{array}{lll}\text { Miguel } & \text { Vale } & \text { de } \\
\text { Almeida } & & \end{array}$ & $\begin{array}{l}\text { Silvia Favero Arend } \\
\text { Cintia Crescéncio } \\
\text { Juliana Kroeger } \\
\text { Raquel C. dos Santos }\end{array}$ & Anthropology & Pottugal \\
\hline 20 & $2 / 2012$ & Amet Suess & Berenice Bento & Sociology & Spain \\
\hline 20 & $3 / 2012$ & Luiza Bairros & Sónia E. Alvarez & Sociology & Brazil \\
\hline 21 & $1 / 2013$ & Raewyn Connel & $\begin{array}{l}\text { Miriam Adelman } \\
\text { Carmen Rial }\end{array}$ & Sociology & Australia \\
\hline 21 & $2 / 2013$ & \begin{tabular}{|l|} 
Ella Shohat \\
Robert Stam
\end{tabular} & $\begin{array}{l}\text { Emanuelle Santos } \\
\text { Patricia Schor }\end{array}$ & $\begin{array}{l}\text { Cultural Studies and } \\
\text { Literature/Cinema }\end{array}$ & Iraq and USA \\
\hline 21 & $3 / 2013$ & Raquel Platero & Rosa Maria Blanca & Psychology & Spain \\
\hline 22 & $1 / 2014$ & Genevieve Sellier & Ana Maria Veiga & $\begin{array}{l}\text { Literature } \\
\text { Cinema }\end{array}$ & France \\
\hline 22 & $3 / 2014$ & Marie-Hèlène Bourcier & \begin{tabular}{|l} 
Vimicius Kauê Ferreira \\
Miriam Pillar Grossi
\end{tabular} & Philosophy & France \\
\hline 23 & $1 / 2015$ & Claire Moses & $\begin{array}{l}\text { Cristina Scheibe Wolff } \\
\text { Mauricio Pereira Gomes }\end{array}$ & Feminist Theory & USA \\
\hline 23 & $2 / 2015$ & Ilana Lobwy & $\begin{array}{l}\text { Catarina Rea } \\
\text { Luzinete Simòes Minella }\end{array}$ & Biology & France \\
\hline 23 & $3 / 2015$ & Teresa Trautman & Ana Maria Veiga & Cinema & Brazil \\
\hline 24 & $1 / 2016$ & Oscar Guasch & $\begin{array}{l}\text { Antonio Cristian Saraiva } \\
\text { Paiva } \\
\text { Elias Ferreira Veras }\end{array}$ & Sociology & Spain \\
\hline 24 & $2 / 2016$ & Caroline Andrew & $\begin{array}{l}\text { Cintia Lima Crescêncio } \\
\text { Mauricio Pereira Gomes }\end{array}$ & Political Sciences & Canada \\
\hline 24 & $3 / 2016$ & $\begin{array}{l}\text { Ela Wiecko Volkmer } \\
\text { de Castilho }\end{array}$ & $\begin{array}{l}\text { Mauricio Pereira Gomes } \\
\text { Morgani Guzzo }\end{array}$ & Law & Brazil \\
\hline
\end{tabular}

Source: Revista Estudos Feministas.

involved with publishing the journal. Some graduate students also participated with their supervisors. Five male researchers and doctoral students conducted interviews.

As a journal that made a political decision to be designated as dealing with feminist studies (Costa, 2000), issues related to women and feminists occupied nearly all of the articles published in the journal in the 1990s, as can be expected. 
We can perceive that, although discussions about the introduction of the concept of gender in the field of feminist and women's studies (the Women's Studies that had been vigorously developed in countries of the North) took place in Brazil in the 1980s and early 1990s - when the influential article by Joan Scott (1995) was published in a Brazilian academic journal-, studies of masculinities entered REF only later on. The first interview of a male researcher was conducted in 2000 , with U.S. historian James Green. ${ }^{4}$ Although studies of male homosexuality in particular ${ }^{5}$ were brewing since the 1980 s, with journalistic publications such as the Lampião da Esquina, and with many books published (Peter FRY, 1983; João Silvério TREVISAN, 1986; Nestor PERLONGHER, 1987; Teresa SELL, 1987; Edward MacRAE, 1990; Richard PARKER, 1991; James GREEN, 1999), their consolidation in academic periodicals in the field of gender studies was slower and more recent (LAGO, Cristina Scheibe WOLFF, 2013; SCAVONE, 2013). ${ }^{6}$

Another table (table 3 ) considers the dossiers in issues of REF published until v. 25/ 2017. The Dossiê section was organized in the initial proposal of REF to serve as a bridge with social movements, and the mission of the journal was defined as to publish "consistent and innovative theoretical reflections (...) expanding the borders of academic debates in the field of feminist and gender studies and to support the practices of women's movements". About the role of the Dossiê section, and analyses of the dossiers published, a few important reflections have been made, highlighted by that of Sônia Maluf (2004). In the Appendix we present a revision of the chart prepared for the roundtable about feminist publications at Doing Gender Seminar 11, which provides an overview of the issues addressed by the dossiers published in REF until 2017, and with the presentation of their organizers.

Table 3 - Dossiers Table

\begin{tabular}{|l|l|l|l|}
\hline Vol. & Issue/Year & Organizers & Themes \\
\hline 0 & 1992 & & Woman and Environment \\
\hline 1 & $1 / 1993$ & & Woman and Violence \\
\hline 1 & $2 / 1993$ & & Woman and Reproductive Rights \\
\hline 2 & Sp. Issue/1994 & & Colloquium Brazil/France/Quebec \\
\hline 2 & $2 / 1994$ & Eli Diniz & Leila Diniz \\
\hline 2 & $3 / 1994$ & & Feminism Today \\
\hline 3 & $1 / 1995$ & & The 4th World Conference on Women \\
\hline 3 & $2 / 1995$ & Matilde Ribeiro & Black Women \\
\hline 4 & $1 / 1996$ & Lena Lavinas & Affirmative Actions \\
\hline 4 & $2 / 1996$ & Lena Lavinas & Public Policies and Poverty \\
\hline 5 & $1 / 1997$ & Alda Britto da Motta & Gender and Old Age \\
\hline 5 & $2 / 1997$ & Ana Arruda Callado & Abortion \\
\hline 6 & $1 / 1998$ & Marilena Villela Corrèa & New Reproductive Technologies \\
\hline 6 & $2 / 1998$ & $\begin{array}{l}\text { Maria Luiza Heilborn } \\
\text { Sergio Carrara }\end{array}$ & Masculinity \\
\hline 7 & 1 and $2 / 1999$ & Bruna Franchetto & Indigenous Women \\
\hline 8 & $1 / 2000$ & $\begin{array}{l}\text { Luzinete Simóes Minella } \\
\text { Maria Juracy Toneli Siqueira }\end{array}$ & Gender Relations and Reproductive Health \\
\hline 8 & $2 / 2000$ & $\begin{array}{l}\text { Sónia E. Alvarez } \\
\text { Mariene Libardoni } \\
\text { Vera Soares }\end{array}$ & Feminist Advocacy \\
\hline
\end{tabular}

${ }^{4}$ In v. 6 n. 2 de 1998, the journal published the Dossiê Masculinidade, organized by Maria Luiza Heilborn and Sérgio Carrara, composed of three articles, all written by women researchers. The first number of this volume of the journal included the pioneer article by Pedro Paulo de Oliveira Discursos sobre a Masculinidade (1998). ${ }^{5}$ The studies about lesbian sexuality have not yet earned visibility in this first moment in Brazil.

${ }^{6}$ This order in the trajectories of studies of women, gender, sexualities, masculinities, is repeated in the various disciplinary fields, more actively in some, in others with a relative delay, as in the field of communication and journalism (MARTINES, Mônica; LAGO, Cláudia; LAGO, Mara. "Estudos de gênero na pesquisa em jornalismo no Brasil: uma tênue relação". Revista Famecos, Porto Alegre, v 23, n. 2, 2016. p 01-23). 


\begin{tabular}{|c|c|c|c|}
\hline 9 & $1 / 2001$ & $\begin{array}{l}\text { Miriam Pillar Grossi } \\
\text { Sónia Malheiros Mignel }\end{array}$ & Women in Politics, Women in Power \\
\hline 9 & $2 / 2001$ & $\begin{array}{l}\text { Guacira Lopes Louro } \\
\text { Dagmar Estermann Meyer }\end{array}$ & Gender and Education \\
\hline 10 & $1 / 2002$ & Luiza Bairros & III World Conference against Racism \\
\hline 10 & $2 / 2002$ & Maria Lucia Mott & Childbirth \\
\hline 11 & $1 / 2003$ & $\begin{array}{l}\text { Luzinete Simòes Minella } \\
\text { Miriam Pillar Grossi }\end{array}$ & $\begin{array}{l}\text { Brazilian Feminist Publications: Sharing } \\
\text { Experiences }\end{array}$ \\
\hline 11 & $2 / 2003$ & $\begin{array}{l}\text { Sónia E. Alvarez } \\
\text { Nalu Faria } \\
\text { Miriam Nobre }\end{array}$ & Feminisms and World Social Forum \\
\hline 12 & $1 / 2004$ & $\begin{array}{l}\text { Anita Brumer } \\
\text { Maria Ignez Paulilo }\end{array}$ & Rural Women from the South of Brazil \\
\hline 13 & $2 / 2005$ & Maria José Rosado-Nunes & Gender and Religion \\
\hline 14 & $2 / 2006$ & $\begin{array}{l}\text { Anna Paula Uziel } \\
\text { Luiz Mello } \\
\text { Miriam Grossi }\end{array}$ & $\begin{array}{l}\text { Conjugalities and Parenthoods of Gays, } \\
\text { Lesbians and Transgenders in Brazil }\end{array}$ \\
\hline 15 & $2 / 2007$ & $\begin{array}{l}\text { Rosineide de L. M. Cordeiro } \\
\text { Russell Parry Scott }\end{array}$ & $\begin{array}{l}\text { Women in Northern and Northeastem Rural } \\
\text { Regions of Brazil }\end{array}$ \\
\hline 16 & $2 / 2008$ & $\begin{array}{l}\text { Carmen Tornquist } \\
\text { Cristiani B. da Silva } \\
\text { Mara C. de S. Lago }\end{array}$ & Abortion \\
\hline 16 & $3 / 2008$ & $\begin{array}{l}\text { Matilde Ribeiro } \\
\text { Flàvia Piovesan }\end{array}$ & 120 Years of the Slavery Abolition in Brazil \\
\hline 17 & $3 / 2009$ & $\begin{array}{l}\text { Alinne Bonetti } \\
\text { Ana Carolina Querino }\end{array}$ & Gender and Race Inequalities Portrait \\
\hline 18 & $3 / 2010$ & $\begin{array}{l}\text { Carmem Susana Tornquist } \\
\text { Teresa Kleba Lisboa } \\
\text { Marcos F. Montysuma }\end{array}$ & Women and Environment \\
\hline 19 & $2 / 2011$ & $\begin{array}{l}\text { Cristiani Bereta da Silva } \\
\text { Paula Regina Costa Ribeiro }\end{array}$ & Gender and Sexuality in School \\
\hline 20 & $2 / 2012$ & $\begin{array}{l}\text { Berenice Bento } \\
\text { Larissa Pelúcio }\end{array}$ & $\begin{array}{l}\text { Living as a Trans: Challenges, } \\
\text { Divergences and Conformity }\end{array}$ \\
\hline 22 & $2 / 2014$ & Karina Bidaseca & $\begin{array}{l}\text { Decolonial Cartographies of the Southern } \\
\text { Feminisms }\end{array}$ \\
\hline 23 & $1 / 2015$ & Rosa Blanca & $\begin{array}{l}\text { Visual Arts: Dialogues with Feminist } \\
\text { and Queer Studies }\end{array}$ \\
\hline 23 & $2 / 2015$ & $\begin{array}{l}\text { Cecilia Maria Bacellar Sardenberg } \\
\text { Miriam Pillar Grossi }\end{array}$ & Reviewing Maria da Penha Law \\
\hline 24 & $2 / 2016$ & Bila Sorj & $\begin{array}{l}\text { Economy, Human Rights and Gender } \\
\text { Equality: a New Agenda? }\end{array}$ \\
\hline 24 & $3 / 2016$ & $\begin{array}{l}\text { Eufémia Vicente Rocha } \\
\text { Miriam Steffen Vieira }\end{array}$ & $\begin{array}{l}\text { Gender Dynamics and Feminisms in } \\
\text { African Contexts }\end{array}$ \\
\hline
\end{tabular}

Source: Revista Estudos Feministas

Backing up the Dossiê section, we have the Thematic section (table 4) which is organized in the same way as the first, but with a more academic focus, without a more direct involvement of militants from political movements among the authors of the texts included.

The table about the sections of REF (table 5) has also been revised to include the period until v. 25, n.3 of 2017 for the section of Thematic Articles, which was created when there were considerations about the convenience of combining various articles that were being considered by reviewers or that had already been evaluated, under a common theme. These sections provide us a clear idea of the issues raised by the journal. 
Table 4 - Thematic Section Table

\begin{tabular}{|c|c|c|c|}
\hline Vol. & Issue/Year & Organizers & Themes \\
\hline 12 & $2 / 2004$ & Nadya A. Guimarães & Gender and Work \\
\hline 13 & $1 / 2005$ & Wivian Weller & Gender and Youth \\
\hline 15 & $3 / 2007$ & $\begin{array}{l}\text { Gláucia de O. Assis } \\
\text { Ethel V. Kosminsky }\end{array}$ & Gender and Contemporary Migrations \\
\hline 17 & $3 / 2009$ & $\begin{array}{l}\text { Cláudia de L. Costa } \\
\text { Sónia E. Alvarez }\end{array}$ & $\begin{array}{l}\text { Translocalities: Towards a Feminist Politics of } \\
\text { Translation }\end{array}$ \\
\hline 19 & $1 / 2011$ & Alice Gabriel & Ecofeminism and Queer Ecologies \\
\hline 19 & $3 / 2011$ & Alexandre F. Vaz & Building Bodies in Sports \\
\hline 23 & $3 / 2015$ & $\begin{array}{l}\text { Cristina Scheibe Wolff } \\
\text { Janine Gomes da Silva } \\
\text { Núcia de Oliveira }\end{array}$ & $\begin{array}{l}\text { Gender, Feminisms and Dictatorships } \\
\text { from the Southern Cone }\end{array}$ \\
\hline 24 & $1 / 2016$ & $\begin{array}{l}\text { Tània Regina de Oliveira } \\
\text { Ramos } \\
\text { Eliane Campello }\end{array}$ & Almanac of Representations \\
\hline 25 & $1 / 2017$ & $\begin{array}{l}\text { Richard Miskolci } \\
\text { Larissa Pelúcio }\end{array}$ & Gender, Sexuality and Contemporary Media \\
\hline 25 & $3 / 2017$ & $\begin{array}{l}\text { Ana Maria Veiga } \\
\text { Rosana C. Kamita }\end{array}$ & Gender, cinema and audiovisual \\
\hline
\end{tabular}

Source: Revista Estudos Feministas

Table 5 - Thematic Articles Table

\begin{tabular}{|c|c|c|c|}
\hline Vet. & LoweYtar & Orgaaizens & Thentive \\
\hline 13 & $3 / 2009$ & $\begin{array}{l}\text { Cristima S. Wolff } \\
\text { Lidta M. V. Prosas }\end{array}$ & Writing History in the Feninine \\
\hline 15 & $1 / 2007$ & $\begin{array}{l}\text { Mariliz Govess de Cirvaluo } \\
\text { Mirizm Adelman } \\
\text { Crisims T. Bocha }\end{array}$ & Gitnder ind Media \\
\hline \multirow[t]{2}{*}{16} & $1 / 2008$ & Elecences M. de Oliveirs & $\begin{array}{l}\text { The Contribtice of the Faninism to Contenporary } \\
\text { Sociolegical Researcla }\end{array}$ \\
\hline & 22008 & Lurinete Sinces Minella & $\begin{array}{l}\text { Body. Sevualigy and Henith: Politics. Specches and } \\
\text { Practical }\end{array}$ \\
\hline 16 & $3 \times 2008$ & \begin{tabular}{|l|} 
Zahidt Lipinacei Muzuat \\
Constincia Lima Dewre
\end{tabular} & 19 Cenoury: What Wonen Irawel \\
\hline 17 & 22009 & Susuns Baméo Fundk & Gevier in Dincomase \\
\hline 18 & $1 / 2010$ & Mara C. de S. Lago & Psy Reflactions and Practices \\
\hline 18 & 22010 & Cristim S. Wolf & Weunes is the Work Would \\
\hline 20 & $3 / 2012$ & Tinis Regina de 0 . Rumos & 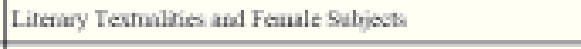 \\
\hline 21 & $1 / 2013$ & $\begin{array}{l}\text { Mara C. de S Lago } \\
\text { Crisina S. Wolf }\end{array}$ & Manculinities. Differenses. Hegenneries \\
\hline 21 & S2013 & $\begin{array}{l}\text { Lime Schuesder } \\
\text { Susars B. Funck }\end{array}$ & Wond and lnage: 16oological Represerations \\
\hline
\end{tabular}

Source: Revista Estudos Feministas 
In addition, with the initial section of articles being varied, and which has been expanding with the online publication of the journal (for a number of reasons) we have a clear idea of the issues raised by the journal, accompanying the developments of feminist and gender studies over these 25 years, with their advances, difficulties and consistencies. There has been a constant dual emphasis on the militance of people involved in publishing the journal in a collective, voluntary and interdisciplinary process.

\section{References}

ALVAREZ, Sônia E. "Constituindo uma política feminista translocal da tradução". Revista Estudos Feministas, Florianópolis, v. 17, n. 3, p. 743-753, 2009.

ANZALDÚA, Gloria. "Falando em línguas: uma carta para as mulheres escritoras do terceiro mundo". Revista Estudos Feministas, Florianópolis, v. 8, n. 1, p. 229-236, 2000.

BAHRI, Deepika. "Feminismo e/no pós-colonialismo". Revista Estudos Feministas, Florianópolis, v. 21 , n. 2, p. 229-236, 2013.

CARDOSO DE OLIVEIRA, Roberto. Tempo e Tradição: Interpretando a Antropologia. Rio de Janeiro: Tempo Brasileiro, 1985. p. 659-688.

COSTA, Albertina. "Revista Estudos Feministas: primeira fase, locação Rio de Janeiro". Revista Estudos Feministas, Florianópolis, v. 12, n. especial, p. 205-210, 2004.

COSTA, Claudia de Lima. "As teorias feministas nas Américas e a política transnacional da tradução". Revista Estudos Feministas, Florianópolis, v. 8, n. 2, 2000, p. 43-48.

DINIZ, Débora; FOLTRAN, Paula. "Gênero e feminismo no Brasil: uma análise da Revista Estudos Feministas". Revista Estudos Feministas, Florianópolis, v. 12, n. Especial, p. 245 253, 2004.

FEMENÍAS, María Luiza. "MORA: la memoria de las revistas académicas". In: FUNCK, Susana B.; MINELLA, Luzinete S.; ASSIS, Gláucia de O. Linguagens e narrativas: desafios feministas. Tubarão: Copiart, 2014. p. 371-387.

FRY, Peter. O que é homossexualidade. São Paulo: Brasiliense, 1983.

FUNCK, Susana B.; MINELLA, Luzinete S.; ASSIS, Gláucia de O. Linguagens e narrativas: desafios feministas. Tubarão: Copiart, 2014.

GREEN, James. Além do Carnaval: a homossexualidade no Brasil do século XX. São Paulo: Saraiva, 1999

LAGO, Mara Coelho de Souza. "A maioridade da Revista Estudos Feministas: entrelaçando experiências". In: FUNCK, Susana B.; MINELLA, Luzinete S.; ASSIS, Gláucia de O. Linguagens e narrativas: desafios feministas. Tubarão: Copiart, 2014. p. 389-425.

LAGO, Mara Coelho de Souza; WOLFF, Cristina Scheibe. "Masculinidades, diferenças, hegemonias". Revista Estudos Feministas, Florianópolis, v. 21, n. 1, p. 233-240, 2013.

LUGONES, Maria. "Rumo a um feminismo descolonial". Revista Estudos Feministas, Florianópolis, v. 22, n. 3, p. 935-952, 2013.

MacRAE, Edward. A construção da igualdade: identidade sexual e política no Brasil da abertura. Campinas: EDUnicamp, 1990.

MALUF, Sônia W. "As edições eletrônicas da REF (e a democratização do acesso à produção acadêmica e científica)". Revista Estudos Feministas, Florianópolis, v. 16, n. 1, p. 123127, 2008.

MALUF, Sônia W. "Os dossiês da REF: além das fronteiras entre academia e militância". Revista Estudos Feministas, Florianópolis, v. 12, n. especial, p. 235-243, 2004.

MENEGHINI, Roberto. Os periódicos científicos brasileiros e seus editores. 2013. Disponível em: http://eventos.scielo.org/encontro-ciencias-humanas/files/2013/05/Rogerio_Meneghini. pdf. Acesso em: 23/03/2017. 
MINELLA, Luzinete Simões. "Fazer a REF é fazer política: memórias de uma metamorfose editorial". Revista Estudos Feministas, Florianópolis, v. 16, n. 1, p. 105-1 16, 2008.

MOSES, Claire G. "A política das publicações feministas". In: FUNCK, Susana B.; MINELLA, Luzinete S.; ASSIS, Gláucia de O. Linguagens e narrativas: desafios feministas. Tubarão: Copiart, 2014. p. 361-370.

MUZART, Zahidé Luppinacci. "Editora Mulheres: o que contar?" In: FUNCK, Susana B.; MINELLA, Luzinete S.; ASSIS, Gláucia de O. Linguagens e narrativas: desafios feministas. Tubarão: Copiart, 2014. p. 427-442.

PARKER, Richard. Corpos, prazeres e paixões: a cultura sexual no Brasil contemporâneo. São Paulo: Best Seller, 1990.

PERLONGHER, Nestor. O negócio do michê: prostituição viril em São Paulo. São Paulo: Brasiliense, 1987.

PRATT, Mary Louise. "Por uma Perspectiva crítica feminista. Entrevista realizada por Claudia de Lima Costa e Alai Garcia Diniz". Revista Estudos Feministas. Rio de Janeiro; Florianópolis, v. 7, n. 1 e 2, p. 127-140, 1999.

SANTOS, Emanuelle; SHOR, Patrícia. "Brasil, estudos pós-coloniais e contracorrentes análogas. Entrevista com Ella Shohat e Robert Stam". Revista Estudos Feministas, Florianópolis, v. 21 , n. 2, p. 701-726, 2013.

SCAVONE, Lucila. "Violências: um olhar sobre a Revista Estudos Feministas". In: FUNCK, Susana B.; MINELLA, Luzinete S.; ASSIS, Gláucia de O. Linguagens e narrativas: desafios feministas. Tubarão: Copiart, 2014, p. 407-425.

SCAVONE, Lucila. "Perfil da REF dos anos 1999 a 2012". Revista Estudos Feministas, Florianópolis, v. 21, n. 2, p. 587-596, 2013.

SCOT, Joan W. "Gênero: uma categoria útil de análise histórica". Revista Educação e Realidade, Porto Alegre, v. 20, n. 2, p. 71-99, 1995.

SELL, Teresa. A identidade homossexual e a manutenção da norma. Florianópolis: EDUFSC, 1987.

SHOHAT, Ella. "A vinda para a América: reflexões sobre perda de cabelos e de memória". Revista Estudos Feministas, Florianópolis, v. 10, n. 1, 2002, p. 99-117.

TREVISAN, João Silvério. Devassos no Paraíso. São Paulo: Max Limonad, 1986.

[Received on $08 / 08 / 2018$

and accepted on $22 / 08 / 2018]$

Vicissitudes da internacionalização: artigos acadêmicos em revistas brasileiras Resumo: Em 2017 a Revista Estudos Feministas completa 25 anos de publicação. Seus 10, 15 e 20 anos como revista acadêmica criada e editada por coletivos de mulheres ligadas à docência, pesquisa e militância feminista renderam muitos textos em edições comemorativas. A REF, fruto de trabalho coletivo voluntário, "é um periódico indexado, interdisciplinar, de circulação nacional e internacional, cuja missão é publicar artigos, ensaios e resenhas que apresentem reflexões teóricas consistentes e inovadoras (...), ampliando fronteiras dos debates acadêmicos no campo dos estudos feministas e de gênero e instrumentando as práticas dos movimentos de mulheres". Os 25 anos da revista nos proporcionam nova ocasião para refletir sobre seus processos de edição, sobre os temas de artigos, ensaios, dossiês, debates publicados, sobre os lugares geográficos e de formações disciplinares de autoras/es que nela publicam(ram), com suas diversificadas filiações epistemológicas, agora com o apoio de banco de dados organizado sobre a revista.

Palovras-chave: Revista Estudos Feministas; autorias; temas; diversidade 
Mara Coelho de Souza Lago (maralago7@gmail.com) holds an MA in Anthropology from the Federal University of Santa Catarina (UFSC) and a PhD in Psychology of Education from the State University of Campinas (Unicamp), Brazil. She is Professor Emerita of Psychology at UFSC. Since her retirement, she has worked voluntarily in the Graduate Programs of Psychology and of Interdisciplinary Human Sciences. She is one of the coordinators of the research center "Ways of Life, Family and Gender Relations" (MARGENS/PSI), of the Institute of Gender Studies (IEG) and of the Revista Estudos Feministas (REF). Her teaching and research interests as well as her many publications are related to gender issues, the social sciences and interdisciplinarity.

(iD) 0000-0001-5111-8699

14 Revista Estudos Feministas, Florianópolis, 26(3): e58654 